OPEN ACCESS

Edited by:

Nuria Ferrol,

Consejo Superior de Investigaciones Cientificas (CSIC), Spain

Reviewed by:

María Soledad Vásquez-Murrieta, Instituto Politécnico Nacional, Mexico

Gyöngyvér Mara

Sapientia Hungarian University

of Transylvania, Romania

*Correspondence:

Jennifer Mesa-Marín

jmesam@us.es

Specialty section:

This article was submitted to

Plant Microbe Interactions,

a section of the journal

Frontiers in Plant Science

Received: 09 April 2018 Accepted: 25 September 2018

Published: 17 October 2018

Citation:

Mesa-Marín J, Del-Saz NF, Rodríguez-Llorente ID, Redondo-Gómez S, Pajuelo E,

Ribas-Carbó $M$ and Mateos-Naranjo E (2018) PGPR

Reduce Root Respiration and Oxidative Stress Enhancing Spartina maritima Root Growth and Heavy Metal Rhizoaccumulation.

Front. Plant Sci. 9:1500. doi: 10.3389/fpls.2018.01500

\section{PGPR Reduce Root Respiration and Oxidative Stress Enhancing Spartina maritima Root Growth and Heavy Metal Rhizoaccumulation}

\author{
Jennifer Mesa-Marín ${ }^{1 *}$, Néstor Fernández Del-Saz',3, Ignacio D. Rodríguez-Llorente4, \\ Susana Redondo-Gómez ${ }^{1}$, Eloísa Pajuelo ${ }^{4}$, Miquel Ribas-Carbó ${ }^{2}$ and \\ Enrique Mateos-Naranjo ${ }^{1}$
}

\begin{abstract}
${ }^{1}$ Departamento de Biología Vegetal y Ecología, Facultad de Biología, Universidad de Sevilla, Seville, Spain, ${ }^{2}$ Grup de Recerca en Biologia de les Plantes en Condicions Mediterrànies, Universitat de les Illes Balears, Palma, Spain, ${ }^{3}$ Departamento de Botánica, Facultad de Ciencias Naturales y Oceanográficas, Universidad de Concepción, Concepción, Chile, ${ }^{4}$ Departamento de Microbiología y Parasitología, Facultad de Farmacia, Universidad de Sevilla, Seville, Spain
\end{abstract}

The present study aims to unravel ecophysiological mechanisms underlying plantmicrobe interactions under natural abiotic stress conditions, specifically heavy metal pollution. Effect of plant growth promoting rhizobacteria (PGPR) bioaugmentation on Spartina maritima in vivo root respiration and oxidative stress was investigated. This autochthonous plant is a heavy metal hyperaccumulator cordgrass growing in one of the most polluted estuaries in the world. The association with native PGPR is being studied with a view to their biotechnological potential in environmental decontamination. As a novelty, the oxygen-isotope fractionation technique was used to study the in vivo activities of cytochrome oxidase (COX) and alternative oxidase (AOX) pathways. Inoculated plants showed decreased antioxidant enzymatic activities and in vivo root respiration rates. The reduction in respiratory carbon consumption and the stress alleviation may explain the increments observed in S. maritima root biomass and metal rhizoaccumulation after inoculation. For the first time, plant carbon balance and PGPR are interrelated to explain the effect of rhizobacteria under abiotic stress.

Keywords: plant growth promoting rhizobacteria (PGPR), heavy metals, Spartina maritima, root respiration, oxygen-isotope fractionation, oxidative stress, carbon balance, bioremediation

\section{INTRODUCTION}

Heavy metal pollution in soil is one of the most serious ecological problems all over the world, as it causes negative impacts on the ecosystem and plant, animal and human health (Vassilev et al., 2004; Nagajyoti et al., 2010; Ali et al., 2013). Heavy metals cannot be degraded to harmless products, and consequently persist in the environment indefinitely (Garbisu and Alkorta, 2001). Many remediation strategies have been considered to counter the detrimental effects of metal excess in soil (Sharma and Pandey, 2014). Among them, using metal accumulating plants has been receiving increasing attention due to their good potential for success (Burd et al., 2000). 
Spartina maritima (Curtis) Fernald is an indigenous cordgrass that naturally grows in the joint estuary of Tinto and Odiel rivers (SW Spain), one of the most polluted areas by heavy metals in the world (Mesa et al., 2016). This C4 halophyte is an important salt marsh pioneer and ecosystem engineer (Mateos-Naranjo et al., 2010) that possesses a high heavy metal accumulating capacity in tissues, especially in its roots, making it useful for phytoremediation purposes (Redondo-Gómez, 2013). Despite the fact that metal hyperaccumulator plants like $S$. maritima can resist pollution to certain degree, it is well known that exposure to heavy metals triggers a wide range of physiological and biochemical alterations in plants (Singh et al., 2015), ultimately leading to reduced growth and metal phytoaccumulation (Duarte et al., 2013). In this context, the association with plant growth promoting rhizobacteria (PGPR) plays an important role toward enhancement of plant development under heavy metal stress, thus ameliorating phytoremediation capacity of hyperaccumulator plants (Glick, 2010; Rajkumar et al., 2012).

Improvement of $S$. maritima root growth and metal rhizoaccumulation after PGPR inoculation in polluted sediments has been recently demonstrated (Mesa et al., 2015a). This positive effect was mainly mediated by improvement of photosynthetic apparatus performance, linked with a beneficial impact on PSII functionality and chlorophyll concentration. However, despite amelioration in leaf fitness, the bacterial consortium was able to stimulate plant growth and metal uptake chiefly in roots (Mesa et al., 2015a). Taking into consideration that plant growth depends on the accumulation of photosynthetic carbon not consumed during respiration (Ribas-Carbó et al., 2000; González-Meler et al., 2001; Lambers et al., 2008; DelSaz et al., 2016; Flórez-Sarasa et al., 2016), it is reasonable to study both photosynthesis and respiration processes in S. maritima in order to elucidate the manner by which plant growth is increased under PGPR inoculation. With this in mind, it is known that high concentrations of heavy metals greatly alter respiration in plants (Lösch, 2004) by affecting different components of the mitochondrial electron transport chain (mETC) (Keunen et al., 2011). Among them, alternative oxidase (AOX) and cytochrome oxidase (COX) have been, by far, the most studied enzymes of the mETC (Vanlerberghe, 2013). In particular, AOX is thought to play an important role under the stress induced by metal toxicity (Keunen et al., 2011). However, there is no information about the response of the in vivo activities of AOX and COX pathways under metal excess and the possible effects of PGPR inoculation on plant respiration under heavy metal stress. Thus, we hypothesize that previously observed beneficial root effect after bacterial bioaugmentation may be linked to a positive carbon balance at root level. It is plausible that microbial inoculation may alter COX and AOX pathways. Indeed, the scales may be tilted in favor of a greater relative effect on AOX component, due to its significance in plant response against stress that comes with heavy metal exposure. Moreover, it should not be forgotten that other defensive responses, including the activities of antioxidant enzymes that reduce reactive oxygen species (ROS) levels, such as catalase (CAT), guaiacol peroxidase (GPX), and superoxide dismutase (SOD) activate under metal stress, and are also susceptible of bacterial regulation (Dimkpa et al., 2009a,b; Das and Roychoudhury, 2014).

The present study links two fields that are rarely combined: the bioremediation/PGPR literature and the respiratory physiology/carbon balance literature. It aims at describing the ecophysiological response, at the organism level, of the autochthonous cordgrass $S$. maritima after PGPR bioaugmentation in natural heavy metal polluted sediments, with a special emphasis on in vivo root respiration and oxidative stress. It should provide a new insight into our understanding of plant biology in the context of PGPR-associated phytoremediation, with a view to the biotechnological potential of hyperaccumulator plants in environmental decontamination.

\section{MATERIALS AND METHODS}

\section{Plant and Soil Source and Growing Conditions}

In June 2016, $10 \mathrm{~cm}$ diameter clumps of $S$. maritima were randomly collected from a natural population located in a well-drained gently sloping intertidal low-marsh (mean sea level +1.30 m relative to Spanish Hydrographic Zero, SHZ) from the Tinto river salt marsh $\left(37^{\circ} 15^{\prime} \mathrm{N}, 6^{\circ} 58^{\prime} \mathrm{W}\right.$; SW Spain). Clumps were planted in individual plastic pots $(15 \mathrm{~cm}$ high $\times 18 \mathrm{~cm}$ diameter), filled with $1 \mathrm{~kg}$ of soil from the marsh and placed in a glasshouse with temperatures of $21-25^{\circ} \mathrm{C}, 40-60 \%$ relative humidity, natural day light and irrigated with tap water. Pots were kept under these conditions for 1 week and then were randomly assigned to two bioaugmentation treatments (details in the next section). Tap water metal concentrations were: $\operatorname{arsenic}(\mathrm{As})<1 \mu \mathrm{g} \mathrm{1^{-1 }}$, cadmium $(\mathrm{Cd})<1 \mu \mathrm{g}$ $1^{-1}$, copper $(\mathrm{Cu})<0.01 \mathrm{mg} \mathrm{l^{-1 }}$, nickel $(\mathrm{Ni})<5 \mu \mathrm{g} \mathrm{l}^{-1}$, lead $(\mathrm{Pb})<5 \mathrm{\mu g}^{-1}$ and zinc $(\mathrm{Zn})<0.01 \mathrm{mg} \mathrm{l}^{-1}$. Tinto sediment psychochemical properties are given in Table 1, which also shows metal threshold values imposed for remedial action.

\section{Bacterial Strains, Inoculant Solution, and Bioaugmentation Treatment}

Bacteria used in this work were isolated from the rhizosphere of S. maritima grown in the Tinto river estuary, SW Spain (Mesa et al., 2015a). They were identified by PCR amplification and sequencing of the $16 \mathrm{~S}$ rDNA as Bacillus methylotrophicus SMT38 (Accession No. KF962966), Bacillus aryabhattai SMT48 (Accession No. KF962976), Bacillus aryabhattai SMT50 (Accession No. KF962978), and Bacillus licheniformis SMT51 (Accession No. KF962979) (Mesa et al., 2015a). The resistance of these bacteria to different heavy metals and $\mathrm{NaCl}$ was determined on plates containing TSA $0.2 \mathrm{M}$ $\mathrm{NaCl}$ medium (according to sediment conductivity), both supplemented with increasing concentrations of heavy metals or $\mathrm{NaCl}$ from stock solutions (Mesa et al., 2015a). These bacteria showed a high resistance to several heavy metals and metalloids (up to $10 \mathrm{mM} \mathrm{Cu}, 4 \mathrm{mM} \mathrm{Zn,} 18 \mathrm{mM}$ As or 
TABLE 1 | Concentration of arsenic (As), cadmium (Cd), copper (Cu), nickel (Ni), lead (Pb), and zinc (Zn) and physicochemical properties of sediments from Tinto marshes.

\begin{tabular}{|c|c|c|c|c|c|c|}
\hline & \multicolumn{6}{|c|}{ Metal concentration $\left(\mathbf{m g ~ K g}{ }^{-1}\right)$} \\
\hline & As & Cd & $\mathrm{Cu}$ & $\mathrm{Ni}$ & $\mathrm{Pb}$ & $\mathrm{Zn}$ \\
\hline Tinto sediments & $524 \pm 31$ & $4.6 \pm 0.4$ & $2968 \pm 211$ & $34.3 \pm 1.5$ & $610 \pm 38$ & $2576 \pm 192$ \\
\hline Nature park soil ${ }^{2}$ & $>100$ & $>15$ & $>500$ & $>500$ & $>1000$ & $>1000$ \\
\hline Agricultural soil ${ }^{2}$ & $>50$ & $>7$ & $>300$ & $>200$ & $>350$ & $>600$ \\
\hline
\end{tabular}

Physico-chemical properties

\begin{tabular}{|c|c|c|c|c|}
\hline Texture $^{1}$ & $\mathrm{pH}$ & Redox potential (mV) & Conductivity $\left(\mathrm{mS} \mathrm{cm}^{-1}\right)$ & Organic matter (\%) \\
\hline $71 / 19 / 10$ & $6.3 \pm 0.2$ & $195 \pm 12$ & $12.6 \pm 0.5$ & $11.5 \pm 0.6$ \\
\hline
\end{tabular}

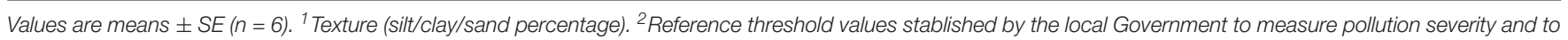
guide corrective actions. Beyond these intervention values, remedial action must be taken in the soil (Junta de Andalucía Consejería de Medio Ambiente, 1999).

$20 \mathrm{mM} \mathrm{Pb}$ ), as well as to $\mathrm{NaCl}$ (up to $2 \mathrm{M} \mathrm{NaCl}$ ). Moreover, these bacteria exhibited multiple plant growth promoting properties, such as nitrogen fixation, phosphate solubilisation, biofilm-forming capacity and production of siderophores and indole-3-acetic acid, demonstrated by several screening tests for plant growth promoting traits (Mesa et al., 2015a). Finally, the four bacterial isolates were cultivated together and none of them showed antagonistic activity against each other (data not shown). To prepare the inoculant solution, bacteria were grown separately in $250 \mathrm{ml}$ Erlenmeyer flasks containing $50 \mathrm{ml}$ of TSB $0.2 \mathrm{M} \mathrm{NaCl}$ medium and incubated under continuous gentle shaking at $28^{\circ} \mathrm{C}$ during $18 \mathrm{~h}$. Then, cultures were centrifuged in $50 \mathrm{ml}$ Falcon tubes at $8000 \mathrm{rpm}$ during $10 \mathrm{~min}$ and the supernatant was discarded. Pellets were washed twice with tap water and finally resuspended in tap water to get a suspension with an $\mathrm{OD}_{600}$ of 1.0 (ca. $10^{8}$ cells per $\mathrm{ml}$ ). Then, equal amounts of the four bacterial suspensions were mixed to get the final inoculant solution. Pots were randomly assigned to two treatments ( $n=12,6$ pots in each one): control non-inoculated plants and inoculated plants. During the assay, pots were slightly watered with tap water every 2 days. For plant inoculation, every pot was watered with $10 \mathrm{ml}$ of the inoculant solution (ca. $10^{9}$ cells per pot) at the beginning of the experiment (Mesa et al., 2015b).

\section{Plant Biomass and Ions Concentration in Plant Tissues}

At the end of the experiment, 30 days after treatment initiation, plants were harvested and separated into roots and shoots and dried at $60^{\circ} \mathrm{C}$ for $48 \mathrm{~h}$ before weighing $(n=6)$.

For tissues ions concentration, leaf and root samples were randomly collected and successively washed with distilled water in order to remove ions from the free spaces and from its surface prior to analysis $(n=6)$. After that, leaf and root samples were ground as previously described in Mateos-Naranjo et al. (2008) and digested with $6 \mathrm{ml} \mathrm{HNO}_{3}, 0.5 \mathrm{ml} \mathrm{HF}$ and $1 \mathrm{ml}$ $\mathrm{H}_{2} \mathrm{O}_{2}$ at $130^{\circ} \mathrm{C}$ for $5 \mathrm{~h}$ in triplicate. Then, $\mathrm{As}, \mathrm{Cd}, \mathrm{Cu}, \mathrm{Ni}, \mathrm{Pb}$, and $\mathrm{Zn}$ were measured by inductively coupled plasma (ICPOES) spectroscopy (ARL-Fison 3410, United States). For quality control, the accuracy and precision of analytical procedure was checked every 5 samples by routine determination of total element concentrations using reference materials from Fisons certified. The average of uncertainty in the determination of elements was in all cases $<2 \%$.

\section{In vivo Root Respiration and Oxygen-Isotope Fractionation Measurements}

Respiration and oxygen isotope fractionation measurements were performed in randomly selected root samples (approximately $300 \mathrm{mg}$ fresh weight, FW) of five replicate plants 1 day before complete plants were harvested for growth analysis.

Roots samples were immediately carefully rinsed using a soft water jet and left to air dry during $15 \mathrm{~min}$ before to be placed in a $3 \mathrm{ml}$ stainless-steel closed cuvette maintained at a constant temperature of $25^{\circ} \mathrm{C}$ (Gastón et al., 2003). The respiration cuvette was equipped with two inlets: one connected to the mass spectrometer (Delta XPlus, Thermo LCC, Bremen, Germany), and the other connected to a $2 \mathrm{ml}$ air-tight syringe. Throughout the experiment the syringe was used to both mix the air in the cuvette and to maintain the cuvette at constant pressure. Air samples of $300 \mu \mathrm{l}$ were sequentially withdrawn from the cuvette and fed into the mass spectrometer. Changes in the ${ }^{18} \mathrm{O} /{ }^{16} \mathrm{O}$ ratios and oxygen concentration were obtained to calculate the oxygen-isotope fractionation and respiration rates (Ribas-Carbó et al., 2005). The electron partitioning to the alternative pathway $\left(\tau_{\mathrm{a}}\right)$ was calculated as follows:

$$
\tau_{\mathrm{a}}=\left(\Delta_{\mathrm{n}}-\Delta_{\mathrm{c}}\right) /\left(\Delta_{\mathrm{a}}-\Delta_{\mathrm{c}}\right)
$$

Where $\Delta \mathrm{c}, \Delta \mathrm{a}$ are the oxygen-isotope fractionation of the cytochrome $(+$ SHAM $)$ and alternative $(+\mathrm{KCN})$ pathway, respectively, and $\Delta_{\mathrm{n}}$, is the oxygen-isotope fractionation of the respiration in the absence of inhibitors. For $\Delta_{\mathrm{a}}$ measurements, roots were submerged in a solution of $10 \mathrm{mM} \mathrm{KCN}$ for $30 \mathrm{~min}$. In addition, a piece of medical wipe wetted with $10 \mathrm{mM} \mathrm{KCN}$ was placed in the cuvette. A value of $\Delta_{\mathrm{a}}$ of $28.03 \pm 0.03 \%$ o $(n=3)$ was obtained. For the calculation of $\Delta_{c}$, roots were submerged in freshly solutions of $25 \mathrm{mM}$ SHAM 
for $30 \mathrm{~min}$. A value of $\Delta_{c}$ for $18.0 \pm 0.06 \%(n=3)$ was obtained.

The individual activities of the cytochrome oxidase pathway, $\operatorname{COP}\left(v_{\text {cyt }}\right)$ and AOX pathway, AOP $\left(v_{\text {alt }}\right)$ were obtained by multiplying the total oxygen uptake rate $\left(\mathrm{V}_{\mathrm{t}}\right)$ and the partitioning to each pathway as follows:

$$
\begin{array}{r}
v_{\text {cyt }}=V_{\mathrm{t}} \times\left(1-\tau_{\mathrm{a}}\right) \\
v_{\mathrm{alt}}=V_{\mathrm{t}} \times \tau_{\mathrm{a}}
\end{array}
$$

\section{Antioxidant Enzymes Assays}

Enzyme extraction was done following the methodology used by Duarte et al. (2015). At the end of experiment, $500 \mathrm{mg}$ of fresh roots and leaf samples were grounded in $8 \mathrm{ml}$ of $50 \mathrm{mM}$ sodium phosphate buffer ( $\mathrm{pH} 7.6)$ with $0.1 \mathrm{mM}$ Na-EDTA and were centrifuged at $10,000 \times g$ for $20 \mathrm{~min}$ at $4^{\circ} \mathrm{C}$ to obtain the soluble proteins. Five samples per inoculation treatment were used and three measurements per sample were registered. Catalase (CAT; EC1.11.1.6) activity was measured according to Teranishi et al. (1974), by monitoring the consumption of $\mathrm{H}_{2} \mathrm{O}_{2}$ and consequent decrease in absorbance at $240 \mathrm{~nm}$ $\left(\varepsilon=39.4 \mathrm{mM}^{-1} \mathrm{~cm}^{-1}\right)$. The reaction mixture contained $50 \mathrm{mM}$ of sodium phosphate buffer ( $\mathrm{pH} 7.6$ ), $0.1 \mathrm{mM}$ of Na-EDTA and $100 \mathrm{mM}$ of $\mathrm{H}_{2} \mathrm{O}_{2}$. The reaction was started with the addition of $100 \mu \mathrm{l}$ of enzyme extract. Guaiacol peroxidase (GPX; EC1.11.1.7) was measured by the method of Bergmeyer et al. (1974), with a reaction mixture consisting of $50 \mathrm{mM}$ of sodium phosphate buffer ( $\mathrm{pH} 7.0$ ), $2 \mathrm{mM}$ of $\mathrm{H}_{2} \mathrm{O}_{2}$ and $20 \mathrm{mM}$ of guaiacol. The reaction was initiated with the addition of $100 \mu \mathrm{l}$ of enzyme extract. The enzymatic activity was measured by monitoring the increase in absorbance at $470 \mathrm{~nm}\left(\varepsilon=26.6 \mathrm{mM}^{-1} \mathrm{~cm}^{-1}\right)$. Superoxide dismutase (SOD; EC1.15.1.1) activity was assayed according to Marklund and Marklund (1974) by monitoring the reduction of pyrogallol and the increase of absorbance at $325 \mathrm{~nm}$. The reaction mixture contained $50 \mathrm{mM}$ of sodium phosphate buffer ( $\mathrm{pH} 7.6), 0.1 \mathrm{mM}$ of Na-EDTA, $3 \mathrm{mM}$ of pyrogallol and Mili$\mathrm{Q}$ water. The reaction was started with the addition of $10 \mu \mathrm{l}$ of enzyme extract. One enzyme activity was defined as the amount of enzyme capable of inhibiting $50 \%$ of the autoxidation of pyrogallol. Control assays were done in the absence of substrate in order to evaluate the auto-oxidation of the substrates. To calculate the enzyme activity per $\mu \mathrm{g}$ of protein, total protein content in leaf and root extracts was determined according to Bradford (1976).

\section{Statistical Analysis}

Statistical analyses were carried out using 'Statistica' v. 6.0 (Statsoft Inc.). The differences between means the two inoculation treatments and between leaf and root ions and antioxidative activity at the end of the experiment were made by using one-way analysis of variance (F-test). Finally, Pearson coefficients were calculated between $\log 10$ transformed-fold changes of the respiratory and antioxidative variables, in order to assess correlations between them. Data were first tested for normality with the Kolmogorov-Smirnov test and for homogeneity of variance with the Brown-Forsythe test.

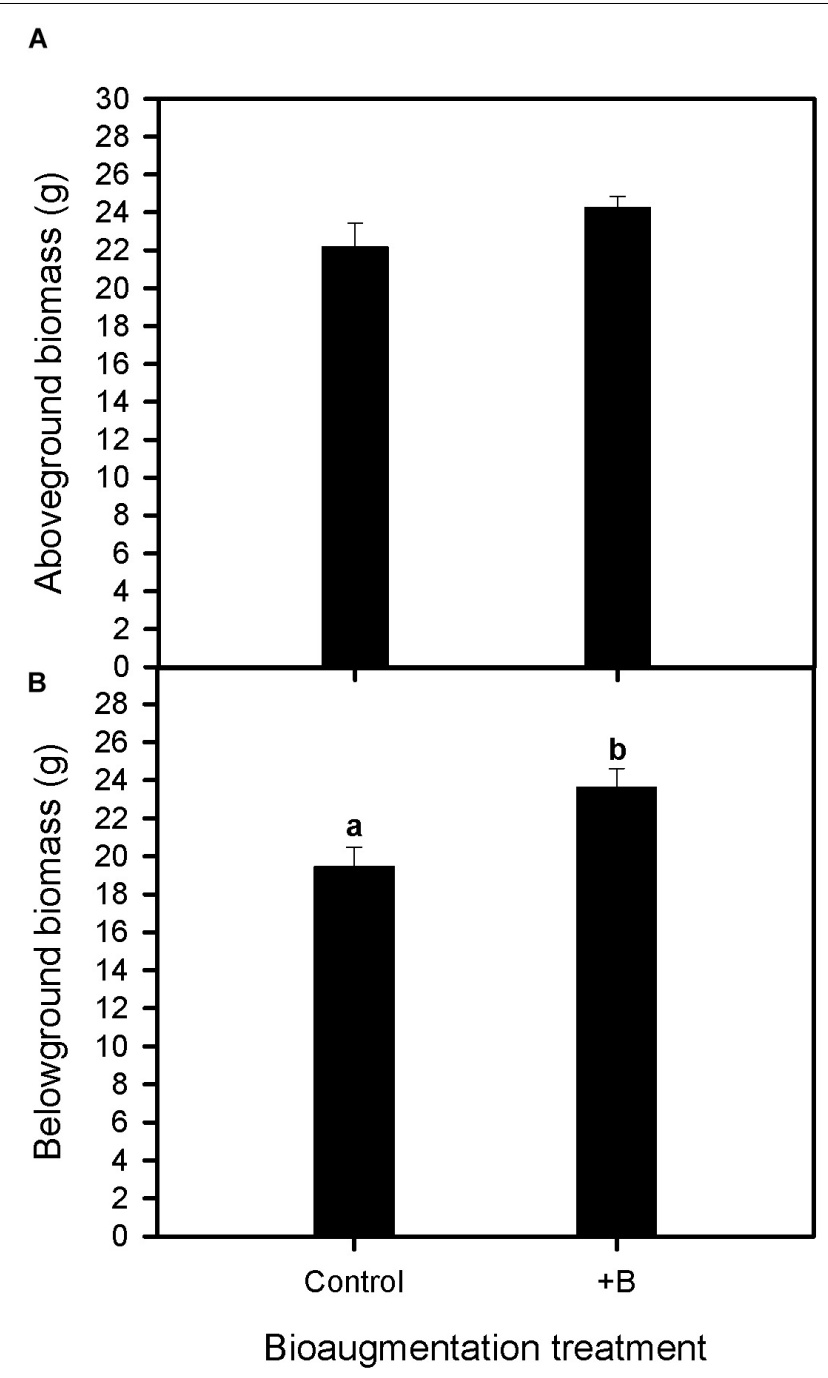

FIGURE 1 | Effect of bioaugmentation with the rhizobacterial consortium $(+\mathrm{B})$ on aboveground biomass $\mathbf{( A )}$ and belowground biomass $\mathbf{( B )}$ in Spartina maritima plants grown in natural sediment from Tinto marsh for 30 days. Values are means $\pm \operatorname{SE}(n=6)$. Different letters indicate means that are significantly different from each other $(F$-test, $P<0.05)$.

\section{RESULTS}

\section{S. maritima Growth Analysis and Ion Tissues Concentrations}

At the end of the experiment (30 days), soil bioaugmentation with the native bacterial consortium increased the belowground biomass of $S$. maritima by about $20 \%$ (one-way Anova, $P<0.05$ ), whereas no significant differences were recorded for aboveground biomass respect to plants grown without bacterial bioaugmentation (Figure 1).

On the other hand, tissue ion concentrations were greater in the roots than in leaves (One-way Anova, $P<0.05$ ) and rhizoinoculation treatment favored the capacity of $S$. maritima to accumulate $\mathrm{As}, \mathrm{Cu}, \mathrm{Cd}$, and $\mathrm{Pb}$ in its roots, being the increment 


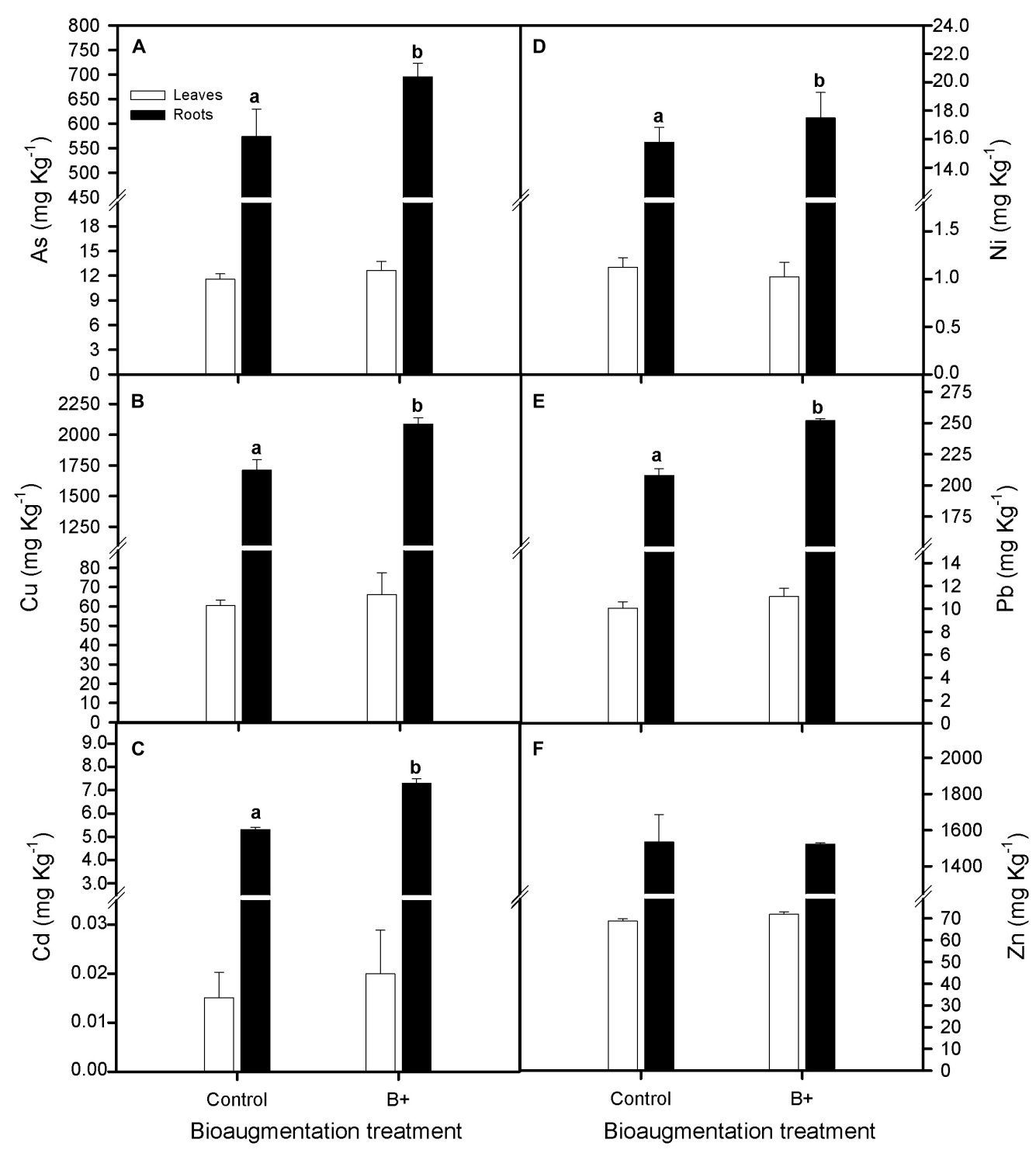

FIGURE 2 | Effect of bioaugmentation with the rhizobacterial consortium ( + B) on total (A) arsenic, As, (B) copper, Cu, (C) cadmium, Cd, (D) nickel, Ni, (E) lead, Pb, and (F) zinc, Zn accumulation for leaves and roots of Spartina maritima grown in natural heavy metal polluted sediment from Tinto marsh for 30 days. Values are means $\pm \operatorname{SE}(n=6)$. Different letters indicate means that are significantly different from each other $(F$-test, $P<0.05)$.

in those ions concentrations of $21,22,37$, and $21 \%$, respectively (one-way Anova, $P<0.05$; Figures $2 \mathrm{~A}-\mathrm{C}, \mathrm{E}$ ), while root and leaves $\mathrm{Ni}$ and $\mathrm{Zn}$ ions concentrations did not vary between both inoculation treatments (Figures 2A-F).

\section{S. maritima in vivo Root Respiration and Oxygen-Isotope Fractionation Measurements}

Our results showed that total respiration rate $\left(V_{\mathrm{t}}\right)$ in $S$. maritima roots decreased considerably when the rhizobacterial consortium was used (Figure 3A). This reduction reached a $44.1 \%$ (oneway Anova, $P<0.05$, Figure 3A). The electron partitioning to the AOX pathway provided a downscaling approach of these differences between both inoculation treatments in respiratory activity. Thus, the lower $V_{\mathrm{t}}$ was accompanied by a notable diminishing of the electron partitioning to the alternative pathway $\left(\tau_{\mathrm{a}}\right)$ in inoculated plants, being this reduction of $59.2 \%$ compared with their non-inoculated counterparts (oneway Anova, $P<0.01$, Figure 3B). Furthermore, it should be highlighted that respiratory activity variation was in greater extent due to higher changes in $v_{\text {alt }}$ compared to $v_{\text {cyt }}$. Thus, compared with non-inoculated plants, $v_{\text {alt }}$ and $v_{\text {cyt }}$ decreased 69.7 and $30.8 \%$ respectively (one-way Anova, $P<0.05$; Figures $3 C, D$ ).

\section{Antioxidant Enzymes Activity}

By the end of the experiment, bacterial bioaugmentation treatment increased considerably soluble protein content both 


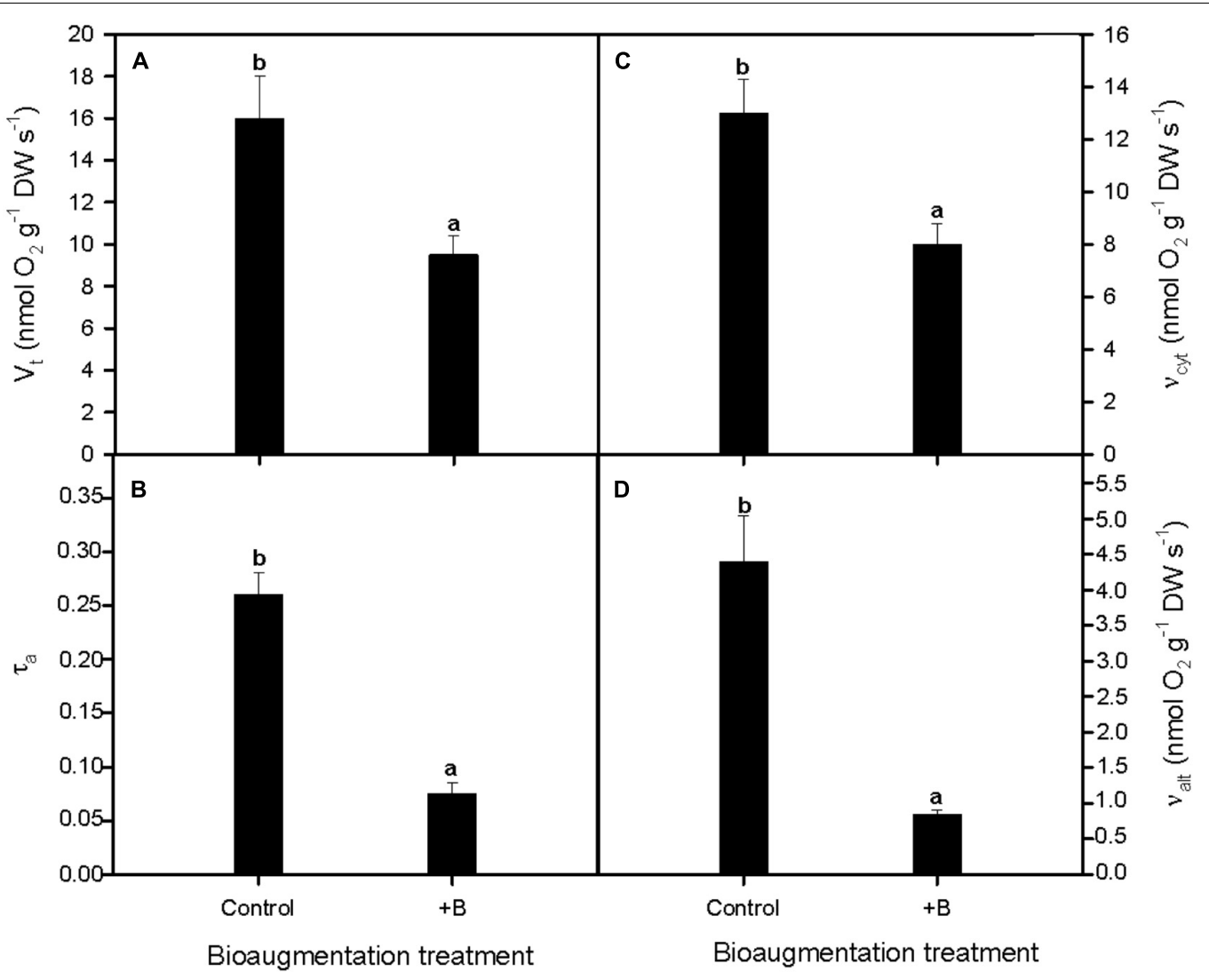

FIGURE 3 | Effect of bioaugmentation with the rhizobacterial consortium ( + B) on in vivo root respiratory activities as determined with the oxygen-isotope fractionation technique. (A) Total respiration rate $\left(V_{\mathrm{t}}\right),(\mathbf{B})$ electron partitioning to the alternative pathway $\left(\tau_{\mathrm{a}}\right)$, and the in vivo activities of $(\mathbf{C})$ cytochrome oxidase $\left(V_{\text {cyt }}\right)$ and (D) alternative oxidase $\left(V_{\text {alt }}\right)$ of $S$. maritima grown in natural heavy metal polluted sediment from Tinto marsh for 30 days. Values are means \pm SE $(n=5)$. Different letters indicate means that are significantly different from each other $(F$-test, $P<0.05)$.

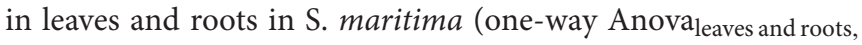
$P<0.05$; Figure 4A). Also, concerning the antioxidative enzymatic activity, we found that CAT, SOD, and GPX activities were higher for roots than for shoots in both inoculation treatments (One-way Anova, $P<0.05$ ) and decreased significantly in roots with bioaugmentation treatment (Figures 4B-D). Thus, compared with non-inoculated plants, these reductions were of 37,48 , and $43 \%$ for CAT, SOD and GPX activities, respectively (one-way Anova, $P<0.05$; Figure 4B-D). Contrarely, bioaugmentation treatment did not have any significative effect on enzyme activities in leaves (Figure 4B-D).

\section{DISCUSSION}

This work analyses for the first time in vivo root activities of COX and AOX pathways during plant respiration in a bioremediation context. As another novelty, the effects of PGPR on the antioxidative enzyme response of $S$. maritima under heavy metal stress are reported. Uncommonly, these studies were carried out under natural heavy metal stress conditions, using natural Tinto estuary sediments, and a non-model plant, given the potential of native $S$. maritima for metal phytoremediation and its utmost important role in estuarine dynamics (MateosNaranjo et al., 2010; Redondo-Gómez, 2013).

Bioaugmentation was the inoculation strategy followed. This is, the addition of competent microorganisms, including the reinoculation of soil with indigenous microorganisms directly isolated from the collection site. The rationale behind this approach, supported by several studies (Vogel, 1996; Thompson et al., 2005), is that a strain derived from a population that is temporally and spatially prevalent in a specific type of habitat, is more likely to persist as an inoculum when reintroduced, than one that is transient or even alien to such a habitat, much more so in polluted scenarios like Tinto saltmarsh. Presumably, these strains are already present in the rhizosphere in the uninoculated treatment, and they have demonstrated to be advantageous for plant growth (Mesa et al., 2015a). But their effect is sub-optimal in these marshes sediments, which shows low bacterial diversity (Mesa et al., 2016). In these cases, increasing the bacterial biocatalyst activity offset the advantages of niche fitness (Vogel, 1996; Kuiper et al., 2004).

Plant growth partly depends on the accumulation of carbon not consumed during respiration. Abiotic stress may decrease growth and induce plants to raise respiration rates in order to fuel 


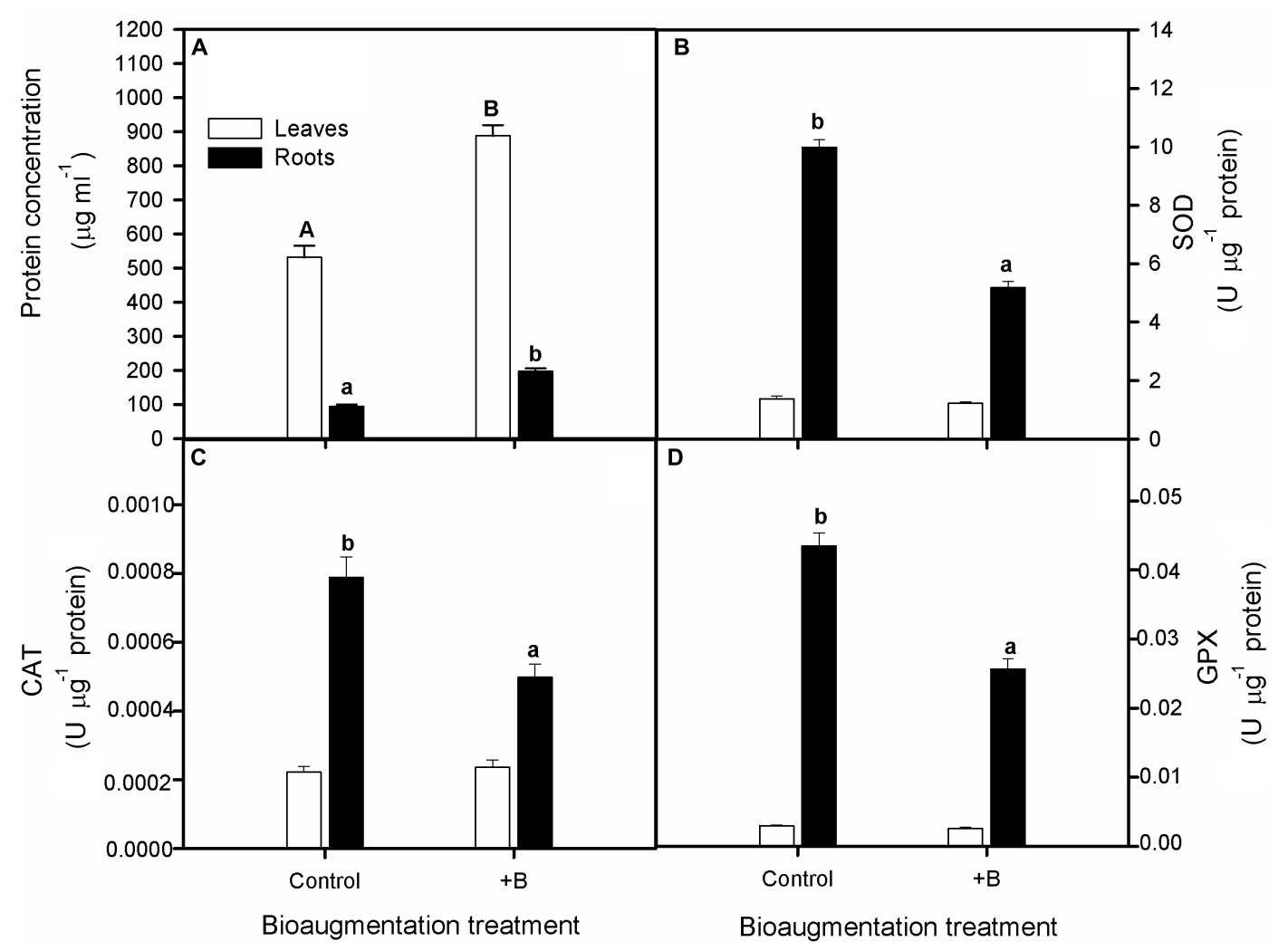

FIGURE 4 | Effect of bioaugmentation with the rhizobacterial consortium ( + B) on soluble protein content (A), catalase, CAT (B), superoxide dismutase (C) and guaiacol peroxidase, GPX (D) enzymatic activities in leaf and roots randomly selected of $S$. maritima grown in natural heavy metal polluted sediment from Tinto marsh for 30 days. Values are means \pm SE $(n=5)$. Different letters indicate means that are significantly different from each other $(F$-test, $P<0.05)$. Capital letters refer to differences in root while lowercase in leaf.

with ATP the maintenance processes. Thus, the present research is based on the hypothesis that beneficial root effect after bacterial bioaugmentation under heavy metal stress may be linked to a positive carbon balance at root level, related to absolute and/or relative alterations of COX and AOX pathways, as well as the decrease of ROS. It is known that increased respiration is a typical plant response to abiotic stress that may lead to increase ATP production (Jacoby et al., 2011, 2013). Also, the activity of AOX has been largely hypothesized to maintain ROS homeostasis under stress (Vanlerberghe, 2013). However, increased rates of total respiration are associated with higher consumption of carbon, leaving less carbon for growth, which does not favor to phytoremediation purposes. Recently, arbuscular mycorrhizal fungus inoculation has shown to decrease root respiration via COX pathway and increase plant growth (Romero-Munar et al., 2017). Continuing our focus on symbiotic relations, bacteria may also influence root respiration rate by the release of some compounds to the rhizosphere (Adesemoye and Egamberdieva, 2013). In this sense, some authors measured root respiration for bacterial inoculation, generally showing an increased root respiration rate (Hadas and Okon, 1987; Phillips et al., 1999; Zhou et al., 2015; Qin et al., 2016). However, the effect of rhizobacterial bioaugmentation in roots has not been tested considering the electron partitioning between the COX and AOX pathways, much less under heavy metal stress. According to results here presented, inoculated S. maritima showed a slower in vivo root respiration rate in heavy metal polluted sediments via both the COX and AOX pathways, with particular emphasis on the AOX pathway, which was not observed for mycorrhizal symbiosis (Romero-Munar et al., 2017). The decrease in total respiration suggests that rhizobacterial inoculation induces in roots much less carbon consumption for maintenance purposes. Contrary to what we observed in inoculated plants, the absence of inoculation is associated with faster respiration that ultimately may lead to increase both carbon consumption and respiratory ATP synthesis (Jacoby et al., 2011).

On the other hand, our results revealed that the slower respiration rate was accompanied with lower activities of antioxidant enzymes in bioaugmented S. maritima plants, suggesting improved plant tolerance under heavy metal stress after rhizobacterial inoculation (Ahemad, 2012; Mesa et al., 2015b). Some authors state that Spartina species possess a well organized and appropriately modulated antioxidative defense system that results in a normal plant development (Martínez Domínguez et al., 2009, 2010). Concretely, S. maritima has shown to have antioxidant feedback responses in the presence of heavy metals (Duarte et al., 2013; Van Oosten and Maggio, 2015), but its enzyme response in polluted scenarios after PGPR inoculation 
was unknown prior to this study. In this work, rhizobacterial bioaugmentation lessened CAT, SOD, and GPX activities in S. maritima roots compared to non-inoculated plants. This is interesting considering that root metal accumulation was higher after inoculation. Then, an increment in the generation of ROS, and consequently antioxidant enzyme activity, would be expected. Although several authors state that rhizobacteria mediates up-regulation of antioxidative enzymes (reviewed in Rajkumar et al., 2012), our data support that bacteria may contribute to the amelioration of abiotic stress not by modulating enzymatic activity, but reducing heavy metal toxicity. For example, siderophores released by the rhizobacterial consortium used (Mesa et al., 2015a) are chelators that may bind metals alleviating their toxicity (Dimkpa et al., 2009a,b). In the same way, selected rhizobacteria produce indoleacetic acid (IAA) (Mesa et al., 2015a), which has a bioprotective effect. Besides, respiration via $\mathrm{AOX}$ is thought to play an important role facing the stress induced by metal toxicity and prevents the generation of ROS (Lösch, 2004; Keunen et al., 2011), but our results showed that this pathway was greatly reduced in inoculated S. maritima. Collectively, these findings suggest that rhizobacterial inoculation induced a decrease in the formation of cell damaging free radicals, thus reducing the need of plant enzymatic defenses (Dimkpa et al., 2009a,b) and may also explain the lessened root activity of AOX in inoculated roots. In noninoculated plants, greater activities of antioxidant enzymes and AOX may indicate a higher S. maritima sensitivity to heavy metal stress, and such phenomena could contribute to maintain ROS homeostasis.

After PGPR inoculation, the physiological adjustments mentioned above were accompanied by an increase in plant soluble protein content, which generally reflects a good plant physiological status (Gepstein, 1988). In shoots, this fact could be related with the amelioration of photosynthetic parameters observed in our previous research (Mesa et al., $2015 b)$, given the likely importance of some proteins quantity, such as Rubisco, in determining plant photosynthetic capacity (Sybesma, 1983; Gepstein, 1988). Although photosynthesis and respiration are rarely studied together, it is advisable because their pathways are intertwined to constitute the entire bioenergetic plant machinery (Lambers and RibasCarbó, 2005). In our previous work, inoculation with the rhizobacterial consortium under the same experimental conditions had a beneficial effect on the photosynthetic apparatus of $S$. maritima, reflected in terms of functionality of PSII, values of $F_{\mathrm{v}} / F_{\mathrm{m}}$ and $\Phi_{\text {PSII }}$ or chlorophyll pigments

\section{REFERENCES}

Adesemoye, A. O., and Egamberdieva, D. (2013). Beneficial Effects of Plant GrowthPromoting Rhizobacteria on Improved Crop Production: Prospects for Developing Economies. Berlin: Springer.

Ahemad, M. (2012). Implications of bacterial resistance against heavy metals in bioremediation: a review. IIOAB J. 3, 39-46.

Ali, H., Khan, E., and Sajad, M. A. (2013). Phytoremediation of heavy metals-concepts and applications. Chemosphere 91, 869-881. doi: 10.1016/j. chemosphere.2013.01.075
(Mesa et al., 2015b). Altogether, increased ATP and carbon availability may permit enhanced biomass formation in inoculated S. maritima, which would explain the increment in root growth in both this study and our previous one (Mesa et al., 2015b).

Results presented here are first findings at the organism level that open interesting hypotheses in plant biology. In summary, we suggest that inoculation of $S$. maritima plants with the native PGPR consortium decreased the activity of antioxidant enzymes and plant respiration, notably falling AOX pathway. Together with ameliorated photosynthesis results obtained in a previous work under the same experimental conditions, it may be elucidated that such processes allow S. maritima to accumulate more carbon for root biomass formation and increase their heavy metal rhizoaccumulation capacity in polluted soils. More experiments are needed with a view to more specific mechanistic approaches, as well as it would be very interesting to know to what extent the structure of the soil microbiota differs between the inoculated versus non-inoculated treatments. Their elucidation may be highly relevant in heavy metal hyperaccumulator plants like S. maritima, given their biotechnological potential in environmental decontamination.

\section{AUTHOR CONTRIBUTIONS}

EM-N, JM-M, and ND-S designed the research. JM-M and ND-S performed the experiments and interpreted the data. JM-M and ND-S wrote the manuscript. EM-N, MR-C, SR-G, EP, and IR-L revised the manuscript.

\section{FUNDING}

This work was supported by Ministerio de Economía y Competitividad, Spain [project CGL2016-75550-R (AEI/FEDER, UE)] and Ministerio de Educación, Cultura y Deporte, Spain (FPU Grant No. AP2012-1809 to JM-M).

\section{ACKNOWLEDGMENTS}

The authors are grateful to Seville University Glasshouse General Services, to Dr. Bernardo Duarte for his assistance during enzyme activities assays and to Biel Martorell for his technical help on the IRMS. 
Das, K., and Roychoudhury, A. (2014). Reactive oxygen species (ROS) and response of antioxidants as ROS-scavengers during environmental stress in plants. Front. Environ. Sci. 2:53. doi: 10.3389/fenvs.2014.00053

Del-Saz, N. F., Florez-Sarasa, I., Clemente-Moreno, M. J., Mhadhbi, H., Flexas, J., Fernie, A. R., et al. (2016). Salinity tolerance is related to cyanide-resistant alternative respiration in Medicago truncatula under sudden severe stress. Plant Cell Environ. 39, 2361-2369. doi: 10.1111/pce.12776

Dimkpa, C., Merten, D., Svatoš, A., Büchel, G., and Kothe, E. (2009a). Metalinduced oxidative stress impacting plant growth in contaminated soil is alleviated by microbial siderophores. Soil Biol. Biochem. 41, 154-162. doi: 10. 1016/j.soilbio.2008.10.010

Dimkpa, C., Weinand, T., and Asch, F. (2009b). Plant-rhizobacteria interactions alleviate abiotic stress conditions. Plant Cell Environ. 32, 1682-1694. doi: 10. 1111/j.1365-3040.2009.02028.x

Duarte, B., Marques, J. C., and Caçador, I. (2015). Impact of extreme heat and cold events on the energetic metabolism of the C3 halophyte Halimione portulacoides. Estuar. Coast. Shelf Sci. 167, 166-177. doi: 10.1016/j.ecss.2015. 10.003

Duarte, B., Santos, D., and Caçador, I. (2013). Halophyte anti-oxidant feedback seasonality in two salt marshes with different degrees of metal contamination: search for an efficient biomarker. Funct. Plant Biol. 40, 922-930. doi: 10.1071/ FP12315

Flórez-Sarasa, I., Ribas-Carbó, M., Del-Saz, N. F., Schwahn, K., Nikoloski, Z., Fernie, A. R., et al. (2016). Unravelling the in vivo regulation and metabolic role of the alternative oxidase pathway in C3 species under photoinhibitory conditions. New Phytol. 212, 66-79. doi: 10.1111/nph.14030

Garbisu, C., and Alkorta, I. (2001). Phytoextraction: a cost-effective plant-based technology for the removal of metals from the environment. Bioresour. Technol. 77, 229-236. doi: 10.1016/S0960-8524(00)00108-5

Gastón, S., Ribas-Carbó, M., Busquets, S., Berry, J. A., Zabalza, A., and Royuela, M. (2003). Changes in mitochondrial electron partitioning in response to herbicides inhibiting branched-chain amino acid biosynthesis in soybean. Plant Physiol. 133, 1351-1359. doi: 10.1104/pp.103.027805

Gepstein, S. (1988). "Photosynthesis," in Senescence and Aging in Plants, ed. L.D. Nooden (San Diego: Academic Press).

Glick, B. R. (2010). Using soil bacteria to facilitate phytoremediation. Biotechnol. Adv. 28, 367-374. doi: 10.1016/j.biotechadv.2010.02.001

González-Meler, M. A., Giles, L., Thomas, R. B., and Siedow, J. N. (2001). Metabolic regulation of leaf respiration and alternative pathway activity in response to phosphate supply. Plant Cell Environ. 24, 205-215. doi: 10.1111/j.1365-3040. 2001.00674.x

Hadas, R., and Okon, Y. (1987). Effect of Azospirillum brasilense inoculation on root morphology and respiration in tomato seedlings. Biol. Fertil. Soils 5, 241-247. doi: 10.1007/BF00256908

Jacoby, R. P., Millar, A. H., and Taylor, N. L. (2013). Investigating the role of respiration in plant salinity tolerance by analyzing mitochondrial proteomes from wheat and a salinity-tolerant amphiploid (wheat $\times$ Lophopyrum elongatum). J. Proteome Res. 12, 4807-4829. doi: 10.1021/pr400504a

Jacoby, R. P., Taylor, N. L., and Millar, A. H. (2011). The role of mitochondrial respiration in salinity tolerance. Trends Plant Sci. 16, 614-623. doi: 10.1016/j. tplants.2011.08.002

Junta de Andalucía Consejería de Medio Ambiente (1999). Los Criterios y Estándares Para Declarar un Suelo Contaminado en Andalucía y la Metodología y Técnicas de Toma de Muestra y Análisis Para su Investigación. Available at: http://www.juntadeandalucia.es/medioambiente/ site/portalweb/menuitem.7elcf46ddf59bb227a9ebe205510e1ca?vgnextoid= 47dbbb45c8bab010VgnVCM1000000624e50aRCRD\&vgnextchannel= 2896a7aaaf4f4310VgnVCM2000000624e50aRCRD

Keunen, E., Remans, T., Bohler, S., Vangronsveld, J., and Cuypers, A. (2011). Metalinduced oxidative stress and plant mitochondria. Int. J. Mol. Sci. 12, 6894-6918. doi: 10.3390/ijms12106894

Kuiper, I., Lagendijk, E. L., Bloemberg, G. V., and Lugtenberg, B. J. J. (2004). Rhizoremediation: a beneficial plant-microbe interaction. Mol. Plant Microbe Interact. 17, 6-15. doi: 10.1094/MPMI.2004.17.1.6

Lambers, H., Chapin, F., and Pons, T. (2008). Plant Physiological Ecology. New York, NY: Springer-Verlag.

Lambers, H., and Ribas-Carbó, M. (2005). Plant Respiration: From Cell to Ecosystem. Dordrecht: Springer Netherlands.
Lösch, R. (2004). "Plant mitochondrial respiration under the influence of heavy metals," in Heavy Metal Stress in Plants, ed. J. M. Palma (Berlin: Springer Berlin Heidelberg), 182-200.

Marklund, S., and Marklund, G. (1974). Involvement of the Superoxide Anion radical in the autoxidation of pyrogallol and a convenient assay for Superoxide Dismutase. Eur. J. Biochem. 47, 469-474. doi: 10.1111/j.1432-1033.1974. tb03714.x

Martínez Domínguez, D., Córdoba García, F., Canalejo Raya, A., and Torronteras Santiago, R. (2010). Cadmium-induced oxidative stress and the response of the antioxidative defense system in Spartina densiflora. Physiol. Plant. 139, 289-302. doi: 10.1111/j.1399-3054.2010.01368.x

Martínez Domínguez, D., Torronteras Santiago, R., and Córdoba García, F. (2009). Modulation of the antioxidative response of Spartina densiflora against iron exposure. Physiol. Plant. 136, 169-179. doi: 10.1111/j.1399-3054. 2009.01227.x

Mateos-Naranjo, E., Redondo-Gómez, S., Andrades-Moreno, L., and Davy, A. J. (2010). Growth and photosynthetic responses of the cordgrass Spartina maritima to CO2 enrichment and salinity. Chemosphere 81, 725-731. doi: 10. 1016/j.chemosphere.2010.07.047

Mateos-Naranjo, E., Redondo-Gómez, S., Cambrollé, J., Luque, T., and Figueroa, M. E. (2008). Growth and photosynthetic responses to copper stress of an invasive cordgrass, Spartina densiflora. Plant Biol. 10, 754-762. doi: 10.1111/ j.1438-8677.2008.00098.x

Mesa, J., Mateos-Naranjo, E., Caviedes, M. A., Redondo-Gómez, S., Pajuelo, E., and Rodríguez-Llorente, I. D. (2015a). Scouting contaminated estuaries: heavy metal resistant and plant growth promoting rhizobacteria in the native metal rhizoaccumulator Spartina maritima. Mar. Pollut. Bull. 90, 150-159. doi: 10. 1016/j.marpolbul.2014.11.002

Mesa, J., Rodríguez-Llorente, I. D., Pajuelo, E., Piedras, J. M. B., Caviedes, M. A., Redondo-Gómez, S., et al. (2015b). Moving closer towards restoration of contaminated estuaries: bioaugmentation with autochthonous rhizobacteria improves metal rhizoaccumulation in native Spartina maritima. J. Hazard. Mater. 300, 263-271. doi: 10.1016/j.jhazmat.2015.07.006

Mesa, J., Mateos-Naranjo, E., Pajuelo, E., Caviedes, M. A., and Rodríguez-Llorente, I. D. (2016). Heavy metal pollution structures soil bacterial community dynamics in SW spain polluted salt marshes. Water Air Soil Pollut. 227:466. doi: 10.1007/s11270-016-3176-5

Nagajyoti, P. C., Lee, K. D., and Sreekanth, T. V. M. (2010). Heavy metals, occurrence and toxicity for plants: a review. Environ. Chem. Lett. 8, 199-216. doi: 10.1007/s10311-010-0297-8

Phillips, D. A., Joseph, C. M., Yang, G. P., Martinez-Romero, E., Sanborn, J. R., and Volpin, H. (1999). Identification of lumichrome as a Sinorhizobium enhancer of alfalfa root respiration and shoot growth. Proc. Natl. Acad. Sci. U.S.A. 96, 12275-12280. doi: 10.1073/pnas.96.22.12275

Qin, S., Zhou, W., Li, Z., and Lyu, D. (2016). Effects of rhizobacteria on the respiration and growth of Cerasus sachalinensis Kom. seedlings. Span. J. Agric. Res. 14:e0803. doi: 10.5424/sjar/2016142-6848

Rajkumar, M., Sandhya, S., Prasad, M. N. V., and Freitas, H. (2012). Perspectives of plant-associated microbes in heavy metal phytoremediation. Biotechnol. Adv. 30, 1562-1574. doi: 10.1016/j.biotechadv.2012.04.011

Redondo-Gómez, S. (2013). Bioaccumulation of heavy metals in Spartina. Funct. Plant Biol. 40, 913-921. doi: 10.1071/FP12271

Ribas-Carbó, M., Robinson, S. A., and Giles, L. (2005). “The application of the oxygen-isotope technique to assess respiratory pathway partitioning," in Plant Respiration, ed. U. I. Balears (Berlin: Springer-Verlag), 31-42.

Ribas-Carbó, M., Robinson, S. A., Gonzalez-Meler, M. A., Lennon, A. M., Giles, L., Siedow, J. N., et al. (2000). Effects of light on respiration and oxygen isotope fractionation in soybean cotyledons. Plant Cell Environ. 23, 983-989. doi: 10. 1046/j.1365-3040.2000.00607.x

Romero-Munar, A., Del-Saz, N. F., Ribas-Carbó, M., Flexas, J., Baraza, E., Florez-Sarasa, I., et al. (2017). Arbuscular mycorrhizal symbiosis with Arundo donax decreases root respiration and increases both photosynthesis and plant biomass accumulation. Plant Cell Environ. 40, 1115-1126. doi: 10.1111/pce. 12902

Sharma, P., and Pandey, S. (2014). Status of phytoremediation in world scenario. Int. J. Environ. Bioremediat. Biodegrad. 2, 178-191. doi: 10.12691/ijebb-2-4-5

Singh, S., Parihar, P., Singh, R., Singh, V. P., and Prasad, S. M. (2015). Heavy metal tolerance in plants: role of transcriptomics, proteomics, 
metabolomics and ionomics. Front. Plant Sci. 6:1143. doi: 10.3389/fpls.2015. 01143

Sybesma, C. (1983). Advances in Photosynthesis Research: Proceedings of the VIth International Congress on Photosynthesis. Brussels: Springer Netherlands.

Teranishi, Y., Tanaka, A., Osumi, M., and Fukui, S. (1974). Catalase activities of hydrocarbon-utilizing Candida yeasts. Agric. Biol. Chem. 38, 1213-1220. doi: 10.1080/00021369.1974.10861301

Thompson, I. P., van der Gast, C. J., Ciric, L., and Singer, A. C. (2005). Bioaugmentation for bioremediation: the challenge of strain selection. Environ. Microbiol. 7, 909-915. doi: 10.1111/j.1462-2920.2005.00804.x

Van Oosten, M. J., and Maggio, A. (2015). Functional biology of halophytes in the phytoremediation of heavy metal contaminated soils. Environ. Exp. Bot. 111, 135-146. doi: 10.1016/j.envexpbot.2014.11.010

Vanlerberghe, G. C. (2013). Alternative oxidase: a mitochondrial respiratory pathway to maintain metabolic and signaling homeostasis during abiotic and biotic stress in plants. Int. J. Mol. Sci. 14, 6805-6847. doi: 10.3390/ijms14046805

Vassilev, A., Schwitzguebel, J. P., Thewys, T., Van Der Lelie, D., and Vangronsveld, J. (2004). The use of plants for remediation of metal-contaminated soils. Sci. World J. 4, 9-34. doi: 10.1100/tsw.2004.2
Vogel, T. M. (1996). Bioaugmentation as a soil bioremediation approach. Curr. Opin. Biotechnol. 7, 311-316. doi: 10.1016/S0958-1669 (96)80036-X

Zhou, W., Qin, S., Lyu, D., and Zhang, P. (2015). Soil sterilisation and plant growth-promoting rhizobacteria promote root respiration and growth of sweet cherry rootstocks. Arch. Agron. Soil Sci. 61, 361-370. doi: 10.1080/03650340. 2014.935346

Conflict of Interest Statement: The authors declare that the research was conducted in the absence of any commercial or financial relationships that could be construed as a potential conflict of interest.

Copyright (c) 2018 Mesa-Marín, Del-Saz, Rodríguez-Llorente, Redondo-Gómez, Pajuelo, Ribas-Carbó and Mateos-Naranjo. This is an open-access article distributed under the terms of the Creative Commons Attribution License (CC BY). The use, distribution or reproduction in other forums is permitted, provided the original author(s) and the copyright owner(s) are credited and that the original publication in this journal is cited, in accordance with accepted academic practice. No use, distribution or reproduction is permitted which does not comply with these terms. 